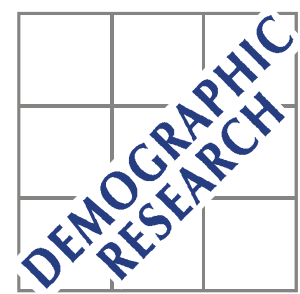

Demographic Research a free, expedited, online journal of peer-reviewed research and commentary in the population sciences published by the Max Planck Institute for Demographic Research Doberaner Strasse 114 · D-18057 Rostock · GERMANY www.demographic-research.org

DEMOGRAPHIC RESEARCH

VOLUME 1, ARTICLE 1

PUBLISHED 1 JULY 1999

www.demographic-research.org/Volumes/Vol1/1/

DOI: 10.4054/DemRes.1999.1.1

\title{
Finnish Life Tables since 1751
}

\section{Väinö Kannisto \\ Mauri Nieminen \\ Oiva Turpeinen}

(C) 1999 Max-Planck-Gesellschaft. 


\title{
FINNISH LIFE TABLES SINCE 1751
}

\author{
Väinö Kannisto, Oiva Turpeinen and Mauri Nieminen
}

\begin{abstract}
A recently completed series of life tables from 1751 to 1995 is used for identifying four stages of mortality transition in Finland, separated by the years 1880, 1945 and 1970. The cyclical fluctuation of the death rate in the eighteenth and nineteenth centuries is measured and examined in relation to epidemics, famines and wars. Important permanent changes in mortality also took place in this early period. Each of the successive stages of transition produced its own characteristic pattern of mortality change which contrasted with those of the other stages. Finally, the age profile of the years added to life is drawn to illustrate the end result of each stage of mortality transition.
\end{abstract}


FINNISH LIFE TABLES SINCE 1751

Väinö Kannisto, Oiva Turpeinen and Mauri Nieminen

\section{INTRODUCTION}

The series of Finnish life tables has recently been extended back to 1751 and forms now an uninterrupted sequence of thirty life tables, first decennial, later quinquennial, spanning a period of 245 years.

The series documents all the different stages of mortality transition from high to low levels in an originally agricultural country which experienced many wars, famines and other crises as well as major political change. Yet, throughout the period in which the population grew from 0.4 million to 5 million, there was no break in the continuity of vital statistics nor in the population base either as a consequence of wars or territorial changes. When certain areas of southeastern* Finland were ceded to Soviet Union in 1940, all their inhabitants moved to other parts of Finland and their registers were likewise transferred.

*Errata: original text read "southwestern." Corrected per communication from author on 3 November 1999

\section{THE DATA}

Unpublished data for 1749-1807 in the archives of Statistics Sweden in Stockholm and likewise mainly unpublished data for 1808-80 at Statistics Finland in Helsinki were collected by Turpeinen and published in the form of 13 decennial life tables covering the years 1751-1880 [38]. Since 1878, deaths in Finland have been published by single year of age and by year of birth and, based on these data, official life tables have been regularly published beginning with one for 1881-90. These tables were recently revised at older ages by the extinct-cohort method and published in a single volume covering the period 1881-1990 [15]. Finally, the tables for 1991-5 have just been published [27].

Though the data on marriages, births and deaths throughout the period are considered very reliable, the population data did not account accurately for the large-scale emigration to North 
America before 1914. This was the main reason for the revision of certain tables mentioned above.

Many countries have been constructing life tables around a census year when the population data are most accurate. In Finland, instead, they have been calculated for 10- or 5-year periods because the quality of register-based, periodically verified population data hardly varies from year to year. An advantage is the absence of time gaps and the larger number of cases recorded over a longer period - important for a small country.

\section{MORTALITY TRANSITION}

The historical development of birth and death rates in Finland is shown in Figure 1. The level of mortality remained essentially unchanged until the second half of the nineteenth century, the death rate was high at all times and frequently raised to sharp peaks by epidemics and famines, sometimes aggravated or caused by wars. At such times, the death rate often exceeded the birth rate. After the last great famine catastrophe of 1866-8, mortality entered a new phase of sustained decline by 1880 . The decline has continued ever since, interrupted only by civil war and influenza in 1918 and wars with Soviet Union in 1939-44. Around 1950 the decline suddenly accelerated due to the introduction of antibiotics, and the crude death rate reached a level where it is no longer a valid indicator of mortality.

The life expectancy at selected ages according to the 30 life tables is given in Table 1. The decennial averages do not effectively smooth out the peaks and troughs of the early periods but leave in evidence a succession of crisis and non-crisis decades. In the pre-transition era, life expectancy was much higher at age 15 than at birth, demonstrating a very high mortality in childhood which was a common feature of the high-mortality regimes of the past. By about 1880 , these two indicators had moved much closer, and in the beginning of the twentieth century they intersected and life expectancy remained decidedly lower at age 15 than at birth as is the rule in low-mortality populations. ${ }^{1}$

Figure 1. Births and deaths per 1000 population in Finland 1750-1995. 
Table 1. Life expectancy in Finland at ages 0, 15 and 65.

\begin{tabular}{|lrrrrrr|}
\hline Life & \multicolumn{5}{c}{ Male } & \multicolumn{3}{c|}{ Female } \\
\cline { 2 - 7 } table & 0 & 15 & 65 & 0 & 15 & 65 \\
\hline $1751-60$ & 36.1 & 44.2 & 11.3 & 38.4 & 44.8 & 11.2 \\
$1761-70$ & 33.9 & 43.3 & 11.1 & 35.8 & 43.6 & 11.0 \\
$1771-80$ & 38.3 & 44.9 & 10.8 & 40.4 & 45.0 & 11.0 \\
$1781-90$ & 32.4 & 39.5 & 9.7 & 35.2 & 41.2 & 10.1 \\
$1791-1800$ & 35.6 & 43.9 & 10.0 & 38.5 & 45.3 & 10.8 \\
& & & & & & \\
$1801-10$ & 30.4 & 37.3 & 8.1 & 33.2 & 39.2 & 8.5 \\
$1811-20$ & 34.5 & 41.9 & 8.9 & 37.1 & 43.6 & 9.7 \\
$1821-30$ & 36.6 & 42.7 & 9.4 & 40.2 & 45.1 & 10.3 \\
$1831-40$ & 33.0 & 39.4 & 8.6 & 36.3 & 41.8 & 9.5 \\
$1841-50$ & 38.4 & 42.9 & 9.5 & 42.5 & 45.8 & 10.4 \\
$1851-60$ & 33.4 & 39.6 & 8.6 & 36.8 & 42.3 & 9.4 \\
$1861-70$ & 30.7 & 37.2 & 7.8 & 33.5 & 39.3 & 8.6 \\
$1871-80$ & 40.3 & 44.8 & 10.2 & 42.9 & 46.4 & 11.0 \\
$1881-90$ & 41.3 & 45.2 & 10.1 & 44.1 & 46.9 & 11.0 \\
$1891-1900$ & 42.8 & 45.6 & 10.2 & 45.7 & 47.7 & 11.2 \\
$1901-10$ & 45.3 & 45.9 & 10.6 & 48.2 & 48.1 & 11.8 \\
$1911-20$ & 43.1 & 40.7 & 10.2 & 49.2 & 47.4 & 11.7 \\
$1921-30$ & 50.2 & 45.1 & 10.5 & 55.0 & 49.6 & 12.3 \\
$1931-40^{*}$ & 53.4 & 46.1 & 10.4 & 59.0 & 51.3 & 12.3 \\
$1941-45^{*}$ & 54.1 & 46.2 & 10.3 & 60.9 & 52.3 & 12.8 \\
$1946-50$ & 58.4 & 48.6 & 10.9 & 65.8 & 55.4 & 13.2 \\
$1951-55$ & 63.4 & 51.7 & 11.1 & 69.9 & 57.6 & 13.3 \\
$1956-60$ & 64.9 & 52.5 & 11.5 & 71.6 & 58.8 & 13.7 \\
$1961-65$ & 65.4 & 52.5 & 11.4 & 72.6 & 59.3 & 13.7 \\
$1966-70$ & 65.9 & 52.5 & 11.3 & 73.3 & 60.0 & 14.2 \\
$1971-75$ & 66.8 & 53.1 & 11.9 & 75.3 & 61.4 & 15.3 \\
$1976-80$ & 68.4 & 54.4 & 12.4 & 77.2 & 63.0 & 16.5 \\
$1981-85$ & 70.1 & 55.8 & 13.1 & 78.4 & 64.1 & 17.3 \\
$1986-90$ & 70.7 & 56.4 & 13.6 & 78.8 & 64.4 & 17.6 \\
$1991-95$ & 72.1 & 57.7 & 14.2 & 79.7 & 65.2 & 18.2 \\
\hline
\end{tabular}

* War deaths excluded. 
The advent of antibiotics is visible in a pronounced increase in life expectancies at all ages in the 1946-50 and 1951-55 life tables but this development soon ran its course and was followed by a slowdown, for adult men even by a reversal. Around 1970 a new development - seen in Table 1 but not in Figure 1 - set in: an unprecedented decline in the mortality of the elderly which raised life expectancies at younger ages as well. It seems therefore appropriate to pinpoint 1880 , 1945 and 1970 as pivot years between important changes in the transition of mortality in Finland. How do these dates stand, in relation to the theory of epidemiologic transition, first proposed by Omran [22]?

A secular, momentous decline in mortality - part of the great demographic transition - began in most Western countries in the mid-nineteenth century or soon thereafter. The long era that it eclipsed, aptly called by Omran "the age of pestilence and famine" could rightly be - and often is called the pre-transition era. Omran, however, called it the first stage of epidemiologic transition and we shall follow this original terminology because it was not an era of basically unchanging, if fluctuating, mortality. In fact, very important permanent changes took place towards the end of it, such as smallpox vaccination, developed by Jenner in the first years of the nineteenth century. This had the major effect of reducing the frequency and magnitude of mortality peaks but did not bring even smallpox under complete control and did by no means spell the end of pestilence.

As to the subsequent stages of transition, Omran's "Age of receding pandemics" (2nd) and "Age of degenerative and man-made diseases" (3rd) have been much criticized for being vaguely and inaccurately defined (e.g. [17]). The timing of the changeover from second to third stage, which is sometimes set at 1930, is also difficult to determine due to lack of clear reference to a cause-of-death classification. Attempts to demarcate the stages by life expectancy at birth have had very questionable results.

If studies by cause of death fail to satisfactorily separate the second from the third stage in Omran's terms, even less can our investigation of all-cause mortality do it. We find no obvious time point of major change before the end of World War II and therefore consider the period 1880-1945 in Finland as one single stage: the second. We shall name it after bacteriology. Although this new science did not actually start the decline of mortality, it gave an explanation to what had begun and gave a completely new understanding of disease processes, opening the way to remarkable advances in the prevention diagnosis and treatment of diseases and in sanitary 
engineering. It was during this stage that the essential transition from high to low mortality - and to the modern world - took place.

We place the beginning of the third stage at the sudden acceleration of mortality decline in the late 1940s as antibiotics proved effective against a wide array of diseases and against infections of the most varied kinds at all ages. This demarcation of the third stage has the merits that the cause is clearly defined and that the onset was virtually simultaneous around the world.

Our latest stage coincides with what is increasingly being recognized as the fourth stage of transition and which has been called that of delayed ageing, a definition we find justified.

Having made this division on the basis of all-cause mortality as measured in a life table, we prefer to speak of stages in mortality (instead of epidemiologic) transition. Such a division has to be made with regard to different ages because looking only at life expectancy at birth we would be uncertain about the third stage and would not notice the fourth at all. To recapitulate, we define the stages of mortality transition in Finland as follows:

$\begin{array}{lll}1^{\text {st }} \text { stage, } & -1880, & \text { era of pestilence and famine } \\ 2^{\text {nd }} \text { stage, } & 1880-1945, & \text { era of bacteriology } \\ 3^{\text {rd }} \text { stage, } & 1945-1970, & \text { era of antibiotics } \\ 4^{\text {th }} \text { stage, } & 1970- & \text { era of delayed ageing }\end{array}$

The respective stages are represented by the following life tables: ${ }^{2}$
$1^{\text {st }}$ from $1751-60$ to $1871-80$, an interval of 120 years
$2^{\text {nd }} \quad$ from $1871-80$ to $1941-45$, an interval of 67.5 years
$3^{\text {rd }} \quad$ from 1941-45 to $1966-70$, an interval of 25 years
$4^{\text {th }}$ from $1966-70$ to $1991-95$, an interval of 25 years

Total interval 237.5 years 
The first stage being the longest and, in Finland as elsewhere, the least known, we shall give more space to a description of it.

\section{FIRST STAGE OF TRANSITION}

This first stage, so called by Omran, has often been seen as a long period of essentially unchanging mortality contrasting with the events that followed. In fact, however, this was not an era without significant developments and we shall in the following demonstrate some permanent changes which took place in Finland during the last century and half of it.

For more remote centuries, information is scarce but a population history since the 1500 s has been written by Jutikkala [7]. Periods of slow population growth alternated with reverses such as a famine in 1601 described by Voipio [44] and a prolonged and severe one in 1696-7, researched by Jutikkala [10] and Muroma [20] among others. The population of Finland which had been estimated at about 1/4 million in 1550, nearly doubled until 1695 but less than 400,000 survived the famine of the next two years [28, p. 21]. This was followed by the long war of 1700-21 between Sweden and Russia in which all of Finland was battleground and most of the churches and priest houses were burned down by the enemy whereby the archives were lost. On the basis of newly started registers, the period 1721-49 has been more thoroughly researched (e.g. [8, 9, $29,36,25])$.

The era of pestilence earned its name from recurrent epidemic diseases as well as endemic ones which were little understood and for which there was scant remedy. In Finland they included smallpox, typhoid and paratyphoid fevers, the usual communicable diseases of childhood, dysentery and occasionally typhus and cholera [33].

Famine, caused by crop failure, was the underlying cause in some crises, particularly in the catastrophes of 1696-7 and 1866-8 although even then fewer died of actual starvation than from diseases [37] which were spread by people who left their homes in quest of food and to which they fell prey in their weakened condition. Apart from actual famine situations, however, the size of crop does not correlate well in this historical material [31, 34]. 
Another cause of catastrophic mortality were wars. Two wars were waged between Sweden and Russia in the period of our early life tables: 1789-90 and 1808-9. The casualties in actual war operations were relatively minor compared with losses from communicable diseases which attacked the combatants but became often even more devastating among the civilian population. The war of 1789-90 was waged in only one frontier province but when peace was made and the soldiers returned home, they spread disease and death among civilians [35]. The losses were very much higher in the second war when the two armies marched and fought back and forth across the entire country. From the peace years 1806-7 to the war years 1808-9 the number of deaths in the total population more than doubled (an increase of 126 percent). Among men of ages 15-39 the number of deaths tripled (an increase of 223 percent) but this increase accounted for only 10 percent of the total increase in deaths, and only part of it were due to combat wounds. Famines and wars of these periods can therefore be called "triggering events" [23] while most deaths were actually caused by infectious diseases.

Besides the constant and often violent fluctuations of the death rate, permanent changes and long-term trends can also be observed during the first stage of transition, particularly since 1750 when more precise data became available. Foremost among these was a significant decline in infant mortality. Strömmer has calculated for it in the period $1750-1850$ a decidedly negative and highly significant $(\mathrm{P}<0.001)$ regression coefficient while for the age-standardized general death rate the regression was only slightly negative and not significant $(\mathrm{P}>0.05)$ [28, pp. 25-26]. Regression analysis of our life tables from 1751-60 to 1871-80 indicates a 23 percent decline in infant mortality. This notable achievement is generally ascribed to efforts of the medical profession to propagate breast-feeding or, more generally, to improvement in child-care practices $[32,24]$.

A fact of historical importance was the gradual control of smallpox through Jennerian vaccination which began soon after 1800. Epidemics of this disease which had been responsible for ten percent of all deaths in the eighteenth century, became less frequent and less lives were lost to them. Complete eradication, however, was not soon achieved, the last epidemics occurring in 1873-4 and 1880-2 after which the lingering presence of a large reservoir of the virus in neighbouring Russia still caused some minor outbreaks e.g. through refugees in the wake of the revolution of 1917 [26]. 
A negative factor was the spread of tuberculosis to Finland in this general epoch [1] raising the death rate of 15-44-year old men sharply. When at the same time the death rate of women of 15-24 increased only slightly and that of 25-44 actually declined, a partial explanation may be a simultaneous decline in maternal mortality.

Finally, the death rates calculated for old ages increased substantially. A similar apparent increase in old age has been observed in Sweden over the same general period, and Hofsten and Lundström [5] have concluded that it was an artefact due to gradual improvement in age information. We have found evidence of similar improvement in the Finnish data during the eighteenth century but do not rule out a real increase in the nineteenth if, for example, an improvement in living standards led to increased consumption of milk products.

Comparing our data for Finland with contemporary life tables for Sweden and England in Table 2 we find a slightly shorter life expectancy in Sweden and a slightly longer one for English men and approximately equal for English women. Age-specific comparisons in Figure 2 give Finland an advantage over Sweden and England in young adult and middle age while in older age groups mortality in Finland exceeds that of England. In these periods, mortality was regularly higher in urban than rural $[28,30]$, and the pronouncedly rural character of Finland with her scattered settlement pattern, low population density and abundant fresh water may have acted to offset the advantage which England and Sweden enjoyed with their greater prosperity, more advanced infrastructure, more favourable climate and absence of war from their soil.

Table 2. Life expectancy at birth in pre-transition Finland compared with Sweden and England.

\begin{tabular}{lllll} 
Sex & Sweden & Finland & England & Finland \\
& $1751-90$ & $1751-90$ & 1841 & $1841-50$ \\
\hline Males & 33.72 & 35.19 & & \\
Females & 36.64 & 37.43 & 40.19 & 38.45 \\
\hline
\end{tabular}

Sweden according to Fritzell [4], England according to English Life Table No. 1 [3]. 
Figure 2. Ratio of mortality in Finland to contemporary mortality in Sweden and England.

There may be populations today with as low and possibly lower life expectancies than mid-eighteenth century Finland but reliable data are rarely available for the most disadvantaged societies. Comparing some data selected from United Nations sources [39] with our earliest Finnish data in Table 3 we find that life expectancy at birth in some countries is now a great deal higher whereas in adult age it remains on the level of the pestilential Europe of two centuries ago. This is the case in countries which display the usual female advantage in survival, as well as in Nepal and India where for cultural reasons the reverse is the case.

Table 3. Life expectancy at birth and at ages 15 and 50.

\begin{tabular}{lcccccc}
\hline $\begin{array}{l}\text { Country } \\
\text { and } \\
\text { period }\end{array}$ & \multicolumn{3}{c}{ Males } & \multicolumn{3}{c}{ Females } \\
\cline { 2 - 7 } & 0 & 15 & 50 & 0 & 15 & 50 \\
\hline Finland 1751-60 & 36.4 & 44.3 & 19.5 & 38.4 & 44.9 & 20.3 \\
Malawi 1977 & 38.1 & 43.8 & 19.7 & 41.2 & 46.2 & 21.2 \\
Rwanda 1978 & 45.1 & 45.4 & 19.9 & 47.7 & 47.4 & 21.7 \\
India 1961-70 & 46.4 & 45.0 & 19.2 & 44.7 & 44.0 & 19.7 \\
Nepal 1981 & 50.9 & 47.3 & 20.3 & 48.1 & 46.9 & 21.2 \\
\hline
\end{tabular}

Source for Malawi, Rwanda, India and Nepal: [39]

For the measurement of the intensity of a mortality crisis, Hollingsworth [6] and Dupaquier [2] have presented indices which we, however, did not find suitable for our particular historical series in which peaks were very frequent and sometimes hardly distinguishable from each other. Instead, to identify crisis years and to measure their intensity, we compared in an earlier publication [38] the crude death rate of each year to "basic mortality" of the epoch which we defined as the mean of the six lowest rates in each sliding 9-year period. Between 1751 and 1880 we found 18 years in which the ratio of actual to basic mortality was 1.3 or higher. The ratio exceeded 2 in the war years $1808-9$ with 2.61 and 2.47 respectively and during the last famine year 1868 with 3.59 . 
We may have a better appreciation of the usual magnitude of short term fluctuations if we leave out the truly exceptional events: the famine of 1866-9 and the wars of 1808-99, 1918 and 1939-44. In the intervening periods the mean annual deviations (up or down) of the crude death rate from basic mortality were the following:

$1755-1807$

$1810-1865$

$1869-1917$

$1919-1938$

$1945-1990$

$1951-1990$
13.4 percent

10.4 percent

6.6 percent

5.0 percent

2.1 percent

(1.3) percent

The regime of sharp peaks and troughs did not come to a sudden end with the onset of the great transition after 1870 but had already been weakened in the nineteenth century, a major reason being smallpox vaccination.

\section{DEVELOPMENT SINCE 1880}

We have placed the beginning of the great secular decline in mortality in Finland at 1880. Since this date, life expectancy has increased until the present day in a sustained manner with only temporary setbacks caused by wars. In certain age groups, nevertheless, some more persistent adverse developments have been observed at times.

The annual decline in age-specific mortality is illustrated in Figure 3 for each stage of transition. In sharp contrast with the sluggish and uncertain changes before it, the long and deep-going second stage (1880-1945) resulted in a thorough transformation of the mortality regime while still leaving some serious problems. Death rates in infancy and childhood were reduced to a third or less of their former levels but for young adults the improvement was much smaller due mainly to the stubborn presence of tuberculosis. For middle-aged women the death rate declined by almost one half but less for the elderly. For men, the decline was altogether more modest and at ages 55-69 suffered an actual setback. Valkonen has found that the mortality of middle-aged and elderly men in Finland rose in the beginning of this century, at least partly 
because of smoking [40] while an increase in the consumption of fats and milk products may also have contributed [41]. An analysis by cause of death made at the end of the second stage indicated that middle-aged men, but not women, had in Finland a much higher death rate from heart diseases than in Sweden [11].

Figure 3. Annual percentage change in mortality by age and sex at different stages of transition.

Throughout the second and later stages of transition until today, infant and child mortality have followed their own path, not always in line with what happened at other ages. The propaganda for better child care which had borne fruit in the preceding centuries, continued after 1900 and a nation-wide system of maternal and child health was founded in the interwar years, a logical continuation, with better means, leading to a substantial decline in infant mortality [24]. The system was developed further after the last war, and by the 1970s virtually all expectant mothers and 97 percent of new-born children were registered at $\mathrm{MCH}$ centres where they had an average of 15 and 12 examinations respectively [21].

An average annual decline of 1-2 percent in childhood mortality translated into a drop of more than 60 percent over the second stage. After that, the decline accelerated and each of the two successive stages, much shorter than the second, also recorded gains of about 60 percent each. Antibiotics obviously played a part but were by no means the prime mover in the development.

The infant mortality rate (IMR) stood in $1881-90$ at 151 per 1000 , with only minor regional differences. When the great decline set in, the more prosperous areas gained an initial advantage and cities overtook rural areas but eventually this development came fill circle, and regional as well as social differences have by now virtually disappeared. ${ }^{3}$ IMR was in mid-century close to 50, still high by European standards but progress has continued until the present when Finland has moved to the forefront in this area with IMR as low as 3.9 in 1995. Improvement in living standards as well as other progress have in Finland as elsewhere been important factors in the reduction of infant mortality but do not explain the above-average success in Finland. We ascribe this achievement to a very successful program of maternal and child health. 
The third stage (1945-1970) began with a sudden acceleration of mortality decline. Most remarkable in the Finnish situation was that the mortality of young adults fell rapidly as tuberculosis, until then a very persistent public health problem, was virtually eliminated as cause of death of the young. Unprecedented survival benefits were experienced at all ages though they were smaller for the oldest. This wave of improvement soon ran its course and was followed by a slowdown in the 1960s. Middle-aged men had recorded at first a much more substantial mortality decline than ever before but by 1960 this had come to a halt and even reversed. This adverse turn has been analysed by Valkonen and ascribed in the first place to changes in health-related behaviour $[40,41]$.

The same did not happen to women for whom additional, though smaller, gains were recorded throughout the third stage. It has to be emphasized that the benefits of the third stage of transition, bestowed largely by antibiotics, were strongly age selective: greatest in childhood and youth after which they took a gradually diminishing form towards old age. While the annual decline of mortality reached 6-8 percent below age 25 , at age 40 it was 2.5 percent for men, 4.5 for women and after age 90 less than one-half percent for both.

The fourth stage of transition was as unexpected as the third. Around 1970, mortality of the elderly began to decline in most Western countries, including Finland, as never before in recorded history and gains in survival were observed even at the highest ages. In Finland the profile of the fourth stage is one in which mortality continues to fall rapidly in infancy and early childhood, is meeting resistance among young adults but declines very substantially in middle age reaching the most rapid rates of decline at about age 60 for men, 70 for women where it has averaged 2.5 percent a year over the last 25 years. Though the decline gradually tapers off towards the oldest ages, it still remains on an entirely unprecedented level even at ages 95 and over where the annual decline amounts to one percent a year.

The gains in survival in old age have been somewhat larger for women than men and their life expectancy at age 65 has increased during the fourth stage by 4.0 years as compared with 2.9 years for men. Yet, at the same time, the very considerable - if belated - improvement in the mortality of middle-aged men has contributed to increase the life expectancy of new-born boys by 6.2 years vs. 6.0 for girls. 
Shown in Figure 3, the difference between the third and fourth stage is very striking for both sexes: the rising curve of the third stage is intercepted in middle age by the declining curve of the fourth as it is heading towards the lowest levels ever observed in old age. We consider this crossover of the decline patterns a distinctive mark of the passage from the third to the fourth stage of mortality transition.

Extensive research on mortality differentials has been carried out in Finland by dividing the entire population into groups according to socio-economic, educational and other classifications and following them up through record-linkage. The general thrust of such studies has been that while death rates have been declining in all groups, the differences between groups have persisted or even increased $[42,1619,18]$. The decline in the mortality from ischemic heart disease is almost fully explained by changes in risk factors [43]. The conclusion is that ample room for further improvement still exists.

\section{YEARS ADDED TO LIFE}

The end result of mortality decline is most properly measured in years added to life. The number of years lived at each age is given by the life table function $L_{X}$ which represents the stationary population. The number of years added to life from one period to another equals the increase in $\mathrm{L}_{\mathrm{X}}$ per person and is shown in Figure 4 by sex and 5-year age group separately for each stage of transition.

Figure 4. Years added to life by age and sex at different stages of transition.

The second stage was very successful in adding young years to life. For males the greatest gains were made before age 20 after which they were gradually frittered away as the death rate in middle age resisted decline and even increased. Nevertheless, as the children saved from death lived on, the transformation which took place was essentially a gain for adult age: a mean age of 35 for men (Table 4). For females, in contrast, further gains were accumulated through middle age, leading to a peak at 60 years, although the mean was 43 . 
In the third stage the dramatic fall in death rates produced smaller gains in childhood and youth because of the already lower level of mortality. Instead, the gains kept increasing vigorously through middle age as a result of successful control of tuberculosis and many other diseases and infections. The years added to life were centered in middle age ( 46 for males, 50 for females) and continued up to old age. Among males, in particular, many more years were added to old age than during the long second stage.

The characteristic feature of the fourth stage of transition has been a decline in the mortality of the elderly and even the very oldest. In infancy and childhood, in spite of the still continuing rapid fall in death rates, relatively few years were added to life and to life expectancy. The gains were instead pushed to ever older age groups. It deserves attention, though, that men have now, belatedly, received great benefits already at ages 50 to 70. The impact of delayed ageing has altogether been felt by men at younger ages than by women, the peaks being observed at 70-74 and 80-84 years respectively while the mean age of the added years was 65 for men and 67 for women. For the first time ever, very substantial gains in survival can be noted even above age 90. On the other hand, however, the precipitous fall of the curves on the right testifies to increasing resistance to prolongation of life close to age 100 .

The relative age distribution of the years added to life (Table 4) provides some concise indicators of the development during the different stages. The great gains of the second stage were relatively evenly distributed to males of all ages but with a slight tendency to older ages among the females. The remarkable fact about the third stage was the great benefits it still gave to working ages. The fourth stage has been subject to diminishing returns for the young and middle-aged, with a corresponding expansion for the elderly on whom any further increase in life expectancy at birth will depend. The mean age of years added to life increased slowly through nearly a century of transition but made a quantum leap during the fourth stage. 
Table 4. Age distribution and mean age of years added to life during each stage of transition.

\begin{tabular}{|rrrrrrr|}
\hline & \multicolumn{3}{c}{ Male } & \multicolumn{3}{c|}{ Female } \\
\cline { 2 - 7 } Age & \multicolumn{1}{c}{$2^{\text {nd }}$} & $3^{\text {rd }}$ & $4^{\text {th }}$ & $2^{\text {nd }}$ & $3^{\text {rd }}$ & $4^{\text {th }}$ \\
\hline $0-14$ & 20.1 & 10.0 & 3.4 & 14.5 & 8.1 & 2.7 \\
$15-64$ & 70.5 & 69.1 & 36.1 & 64.3 & 61.4 & 20.3 \\
$65+$ & 9.4 & 20.0 & 60.5 & 21.2 & 30.5 & 77.0 \\
Total & 100.0 & 100.0 & 100.0 & 100.0 & 100.0 & 100.0 \\
& 35.6 & 45.6 & 64.8 & 43.5 & 50.2 & 67.0 \\
\hline
\end{tabular}

While the first three stages of transition reduced premature mortality, the uniqueness of the fourth stage as illustrated in Figures 3 and 4 and in Table 4, lies in moving the inevitable end of life to a higher age. The earlier stages saved lives, the fourth one delays death.

This opens new vistas for the extension of human life for which considerable scope is seen to exist. On the other hand, gains made in survival have been progressively smaller at higher ages portending a likely slowdown in the future. A projection of the mortality decline of the last 20 years in a group of 13 low-mortality countries up to year 2050 indicates that the modal length of life would then be 92 years for females and 85 for males. Because of some inevitable premature mortality, the life expectancies at birth would be somewhat shorter [14].

Unprecedented and imprevisible developments may of course change the scenario either by prolonging life through scientific breakthroughs or by shortening it by deterioration of the environment or appearance of new diseases or more virulent forms of old ones. Any of these modalities would mean a new, fifth stage in mortality transition.

\section{NOTES}

Väinö Kannisto is Distinguished Research Fellow, Odense University Medical School, Odense, Denmark. Oiva Turpeinen is freelancer who worked in Helsinki University in 1963-96. Mauri Nieminen is Senior Adviser of Population Statistics in Finland. 
${ }^{1}$ The life tables are decennial until 1931-40 and quinquennial beginning with 1941-45. Of these two tables, two versions exist: one based on all deaths and another excluding deaths from war operations. As our main interest in the present study is to describe the mortality transition, we are using the tables from which war deaths are excluded. For earlier wars this distinction was not made and all deaths are included.

${ }^{2}$ Period life tables have often been criticized, even dismissed, for being hybrids because nobody lives his life under one period regime. With equal justification, a cohort life table can be called a hybrid because it depicts a mortality that never existed. Whatever the effects that may be observed in cohort analysis, there is hardly any doubt that the successive stages of mortality transition originated in period events. The varying interpretations of the causes of the secular transition are all based on period factors. In the antibiotics stage the cause is obvious. An analysis of more than 20 low mortality countries has shown that all changes during the fourth stage were simultaneous in all old age groups proving that the development was not caused by supposedly healthier cohorts advancing in age but by something that happened on the time axis [13]. Cohort effects, if any, have in all these cases been overwhelmed by period factors.

${ }^{3}$ The rank correlation coefficient between infant mortality and low socio-economic status for Finnish provinces was in $1871-80$ an insignificant +0.059 rose gradually to +0.87 in 1931-40 and disappeared again into -0.07 in 1979-83 [12]. 


\section{REFERENCES}

1. Backman, W. and S. Savonen (1934). Keuhkotaudin kulku Suomessa 1771-1929. (Pulmonary tuberculosis in Finland 1771-1929). Helsinki.

2. Dupaquier, J. (1979). "L'analyse statistique des crises de mortalité" in: Charbonneau, H. and A. Larose (eds.) The Great Mortalities: Methodological Studies of Demographic Crises in the Past. Liege: Ordina Editions.

3. England. English Life Table No. 1, 1841.

4. Fritzell, Y. (1953). “Överlevelsetabeller för Sverige för 1751-1815” (Survival tables for Sweden 1751-1815). Statistisk Tidskrift 1953, No. 10.

5. Hofsten, E. and H. Lundström (1976). Swedish population history. Main trends from 1750 to 1970. Statistiska Centralbyrån, Stockholm.

6. Hollingsworth, T. (1979). "A Preliminary Suggestion for the Measurement of Mortality Crises" in: Charbonneau, H. and A. Larose (eds.) The Great Mortalities: Methodological Studies of Demographic Crises in the Past. Liege: Ordina Editions.

7. Jutikkala, Eino (1934). "Väestö ja asutus 1500-luvulta 1800-luvun puoliväliin" (Population and settlement from the 16th to mid-19th century) in: Suomen Kulttuurihistoria (Cultural History of Finland) II: 95-115. Helsinki.

8. Jutikkala, Eino (1939). Hämeen väestäolot Uudenkaupungin rauhasta taulustolaitoksen alkuun (1721-49). (Demographic situation in Häme province, 1721-49). Central Statistical Office, Statistical information, 36. Helsinki.

9. Jutikkala, Eino (1945). "Die Bevölkerung Finnlands in den Jahren 1721-49”. Annales Academiae Scientifiarium Fennicae, B LV, 4. Helsinki.

10. Jutikkala, Eino (1955). “The great Finnish famine in 1696-97”. The Scandinavian Economic History Review, III, 1. Uppsala.

11. Kannisto, Väinö (1945). “Mikä lyhentää elinaikaamme?” (What shortens our lives?). Kansantaloudellinen Aikakauskirja (Journal of National Economy) 41: IV: 377-83. Helsinki.

12. Kannisto, Väinö (1986). Geographic differentials in infant mortality in Finland in 1871-1983. Central Statistical Office, Studies No. 126. Helsinki.

13. Kannisto, Väinö (1994). Development of Oldest-Old Mortality 1950-1990. Odense Monographs on Population Aging 1. Odense University Press. Published on the Internet at: http://www.demogr.mpg.de/Papers/Books/Monograph1/OldestOld.htm 
14. Kannisto, Väinö (1996). The Advancing Frontier of Survival. Odense Monographs on Population Aging 3. Odense University Press.

15. Kannisto, Väinö and Mauri Nieminen (1996). Revised Life Tables for Finland 1881-1990. Helsinki, Statistics Finland, Population 1996: 2.

16. Koskinen, S. and T. Martelin (1994). "Kuolleisuus" (Mortality) in: Koskinen, S. et al. (eds.), Suomen väestö (The population of Finland). Hämeenlinna: Gaudeamus.

17. Mackenbach, J. P. (1994). "The epidemiologic transition theory". Editorial. Journal of Epidemiology and Community Health, 48: 329-32.

18. Martelin, Tuija (1996). "Socio-demographic Differentials in Mortality at Older Ages in Finland" in: Caselli, G. and A. D. Lopez (eds.) Health and Mortality Among Elderly Populations. Oxford: Clarendon Press.

19. Martikainen, Pekka (1995). "Mortality and Socio-economic Status Among Finnish Women". Population Studies 49 (1): 71-90.

20. Muroma, S. (1991). Suurten kuolonvuosien (1696-1697) väestönmenetys Suomessa (Loss of life during the years of high mortality, 1696-7). Helsinki: Suomen Historiallinen Seura.

21. National Board of Health (1983). Terveydenhuolto (Health Service). Helsinki.

22. Omran, A. R. (1971). "The epidemiologic transition. A theory of the epidemiology of population change". Milbank Memorial Fund Quarterly, 49 (4): 509-38.

23. Palloni, Alberto (1990). "Assessing the levels and impact of mortality in crisis situations" in Vallin, J. et al. (eds.) Measurement and Analysis of Mortality. Oxford: Clarendon Press.

24. Pitkänen, Kari (1983). "Infant mortality decline in a changing society". Yearbook of Population Research in Finland, XXI: 46-74. Helsinki.

25. Pitkänen, Kari (1988). Väestöntutkismus ja yhteiskunta: suomalaisen väestöntutkimuksen historia 1700-luvulta noin vuoteen 1950 (Demography and society: history of Finnish demographic research from the eighteenth century to about 1950). Publications of the Finnish Demographic Society, No. 11. Helsinki.

26. Pitkänen, K. J., J. H. Mielke and L. B. Joule (1989). "Smallpox and its eradication in Finland: implications for disease control”. Population Studies 43: 95-111.

27. Statistics Finland (1997). Life Tables 1991-95. Population 1997: 4. Helsinki.

28. Strömmer, Aarno (1969). Väestöllinen muuntuminen Suomessa (The demographic transition in Finland). Tornio.

29. Turpeinen, Oiva (1977). "Causal Relationship between Economic Factors and Mortality". Yearbook of Population Research in Finland, XV. Helsinki. 
30. Turpeinen, Oiva (1978). "Infectious Diseases and Regional Differences in Finnish Death Rates, 1749-1773”. Population Studies, 32, 3. London.

31. Turpeinen, Oiva (1979). "Fertility and Mortality in Finland since 1750." Population Studies, 33, 1. London.

32. Turpeinen, Oiva (1979). "Infant Mortality in Finland 1749-1865". The Scandinavian Economic History Review, XXVII, 1.

33. Turpeinen, Oiva (1980). "Die Sterblichkeit an Pocken, Masern und Keuchhusten in Finnland in den Jahren 1751 bis 1865."

34. Turpeinen, Oiva (1980). "Les causes des fluctuations annuelles du taux de la mortalité entre 1750 et 1806". Annales de Demographie Historique. Paris

35. Turpeinen, Oiva (1981). "Mortalitetskrisen i Finland åren 1788-1791" (Mortality crisis in Finland in 1788-1791). Historisk Tidskrift för Finland 1981, 1.

36. Turpeinen, Oiva (1985). Kainuun historia II. Väestö ja talous 1721-1982 (The History of Kainuu II. Population and economy 1721-1982). Kajaani.

37. Turpeinen, Oiva (1986). Nälkä vai tauti tappoi? Kauhunvuodet 1866-1868. (Was hunger or disease the killer? Years of terror 1866-1868). Societas Historica Finlandiae, Helsinki.

38. Turpeinen, Oiva and Väinö Kannisto (1997). Abridged Life Tables for Finland 1751-1880. Statistics Finland, Population 1997: 5. Helsinki.

39. United Nations $(1987,1991)$. Demographic Yearbook. New York.

40. Valkonen, Tapani (1977). Excessive adult male mortality in Finland: its origins and development since 1870. University of Helsinki, Department of Sociology. Working paper No. 3.

41. Valkonen, Tapani (1983). "Transition of mortality in Finland and Sweden" in: Khalatbari, P. (ed.) Demographic Transition, Beiträge zur Demographie No. 7. Humboldt-Universität zu Berlin, pp. 185-208.

42. Valkonen, Tapani, Tuija Martelin, Arja Rimpelä, Veijo Notkola and Soili Savela (1993). Socio-economic mortality differences in Finland 1981-90. Statistics Finland, Population 1993: 1. Helsinki.

43. Vartiainen, Erkki, Pekka Puska, Juha Pekkanen, Jaakko Tuomilehto and Pekka Jousilahti (1994). "Changes in risk factors explain changes in mortality from ischaemic heart disease in Finland”. British Medical Journal 309: 23-27.

44. Voipio, V. (1914). Katovuosi 1601 vaikutuksineen Varsinais-Suomessa (The crop failure of 1601 and its effects in Southwest Finland). Historiallinen Arkisto 24 (1) 6: 9-37. 
Figure 1. Births and deaths per 1000 population in Finland 1750-1995.

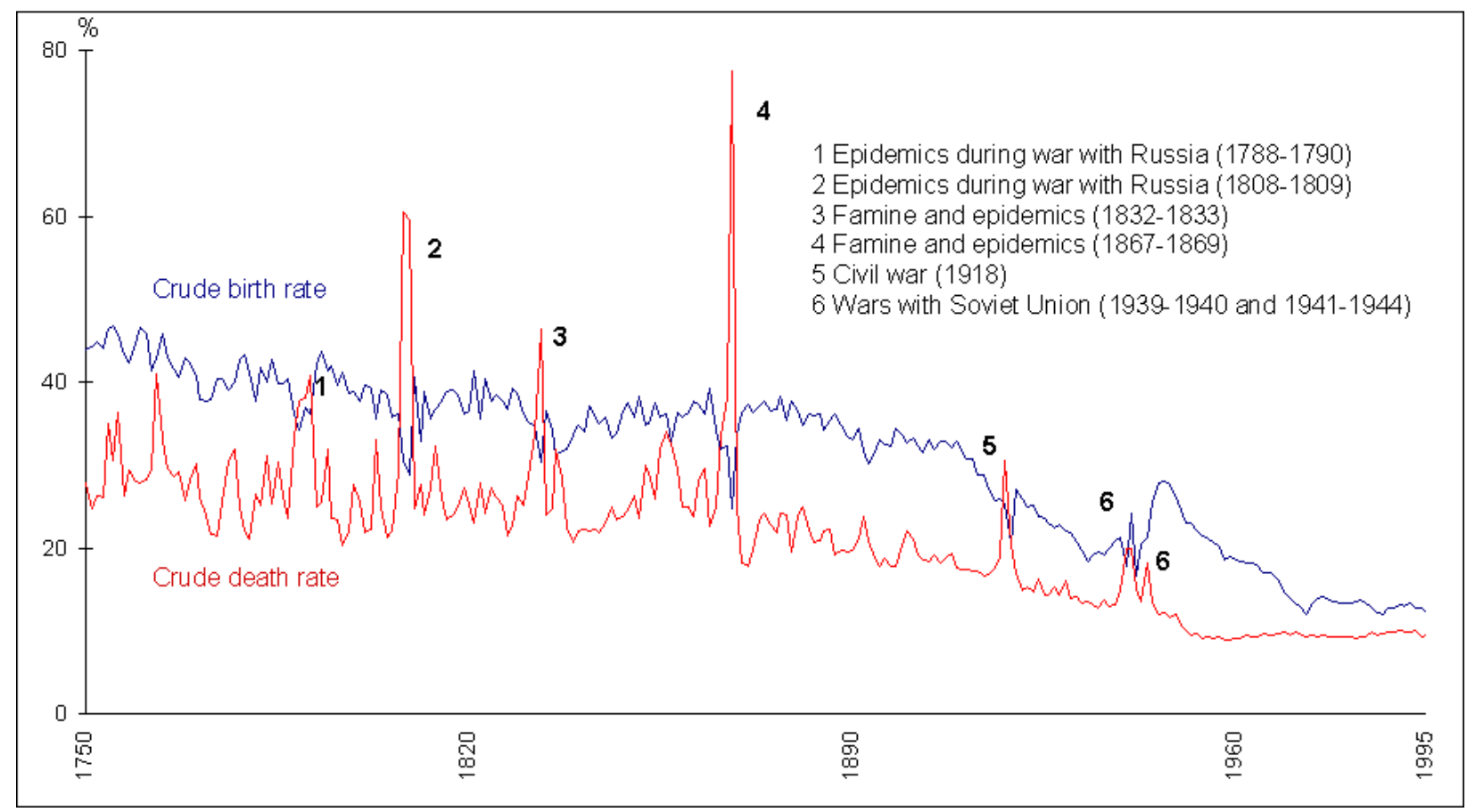


Figure 2. Ratio of mortality in Finland to contemporary mortality in Sweden and England
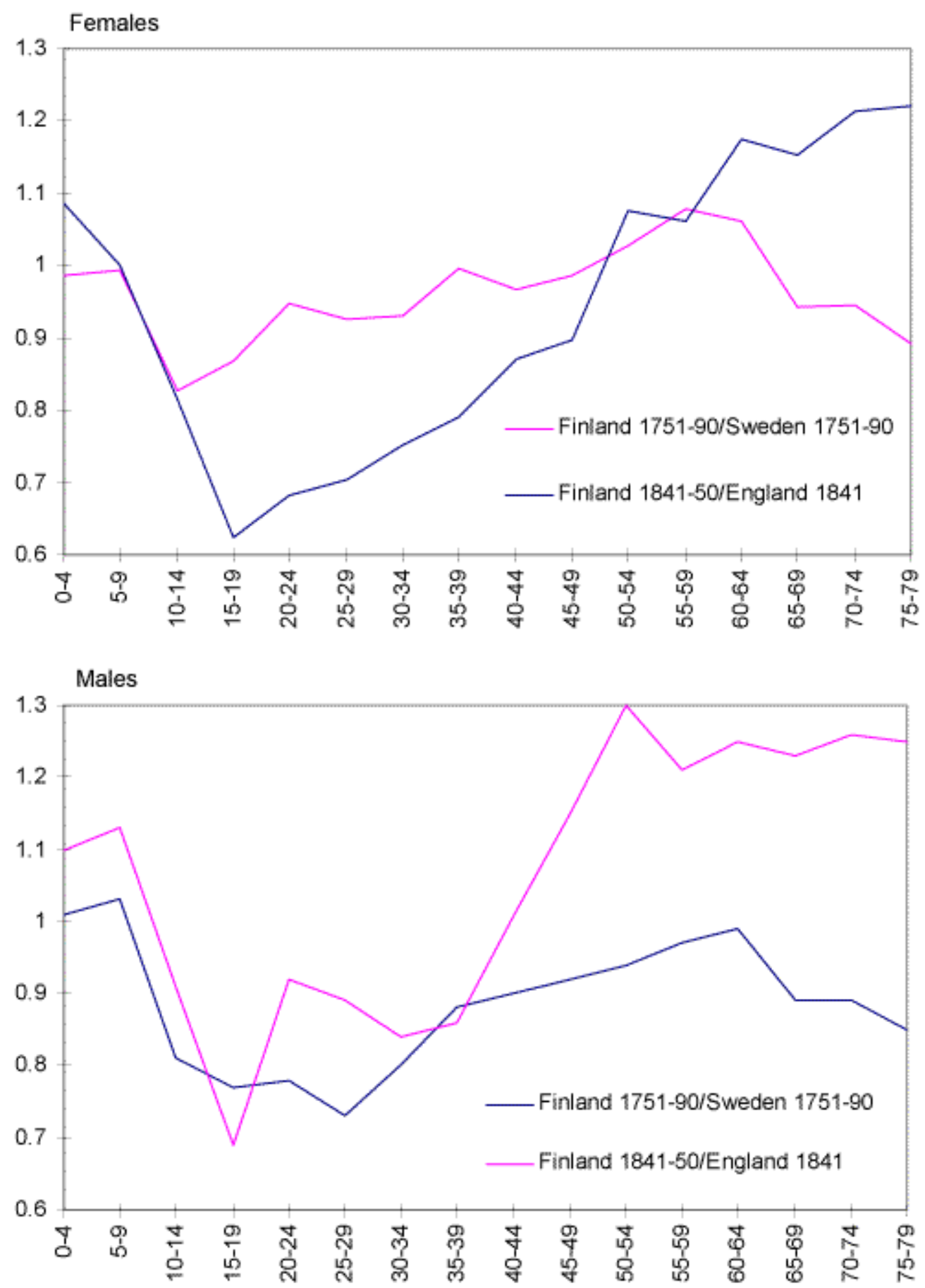
Figure 3. Annual percentage change in mortality by age and sex at different stages of transition. Females

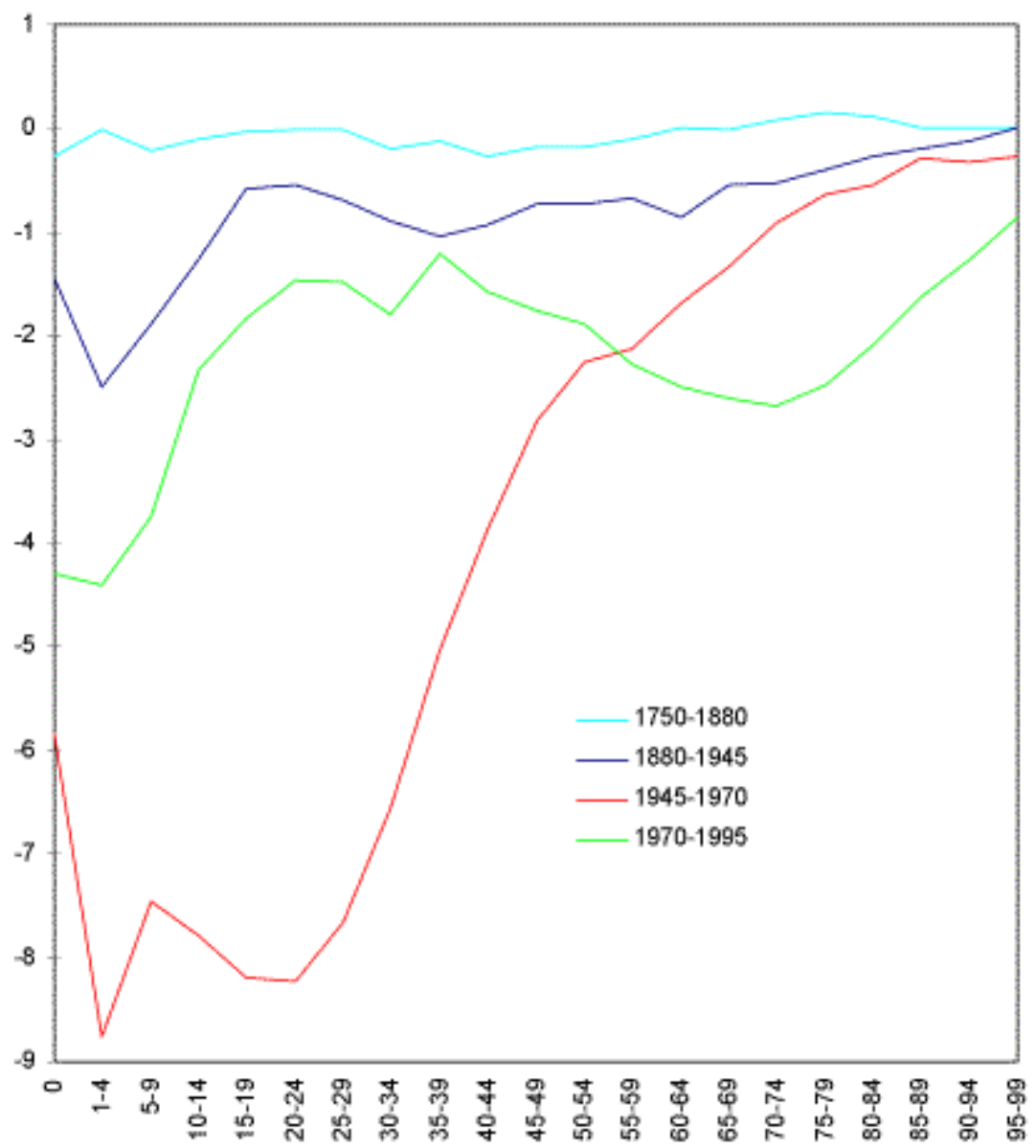


Figure 3. Annual percentage change in mortality by age and sex at different stages of transition. Males

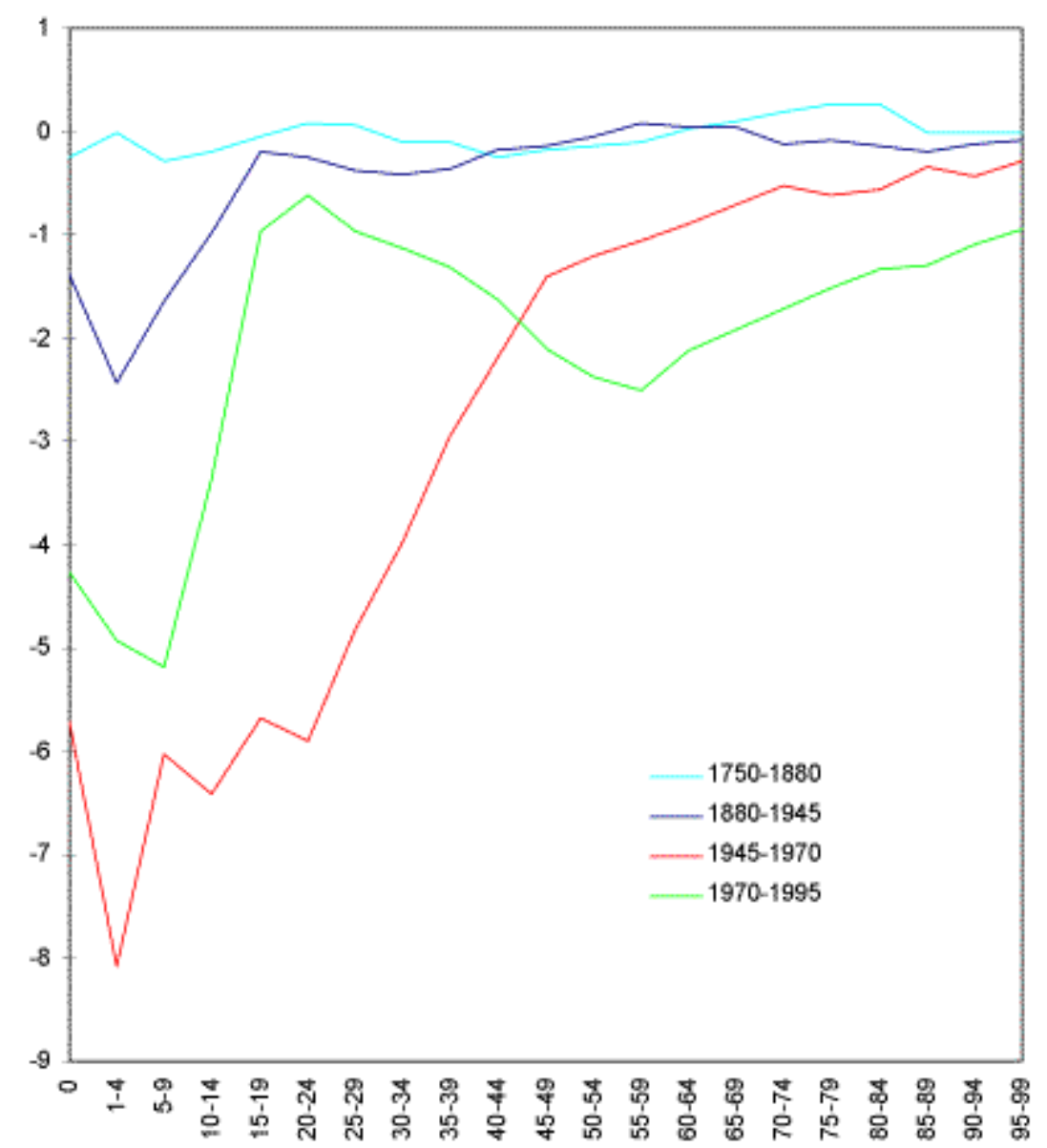


Figure 4. Years added to life by age and sex at different stages of transition. Female

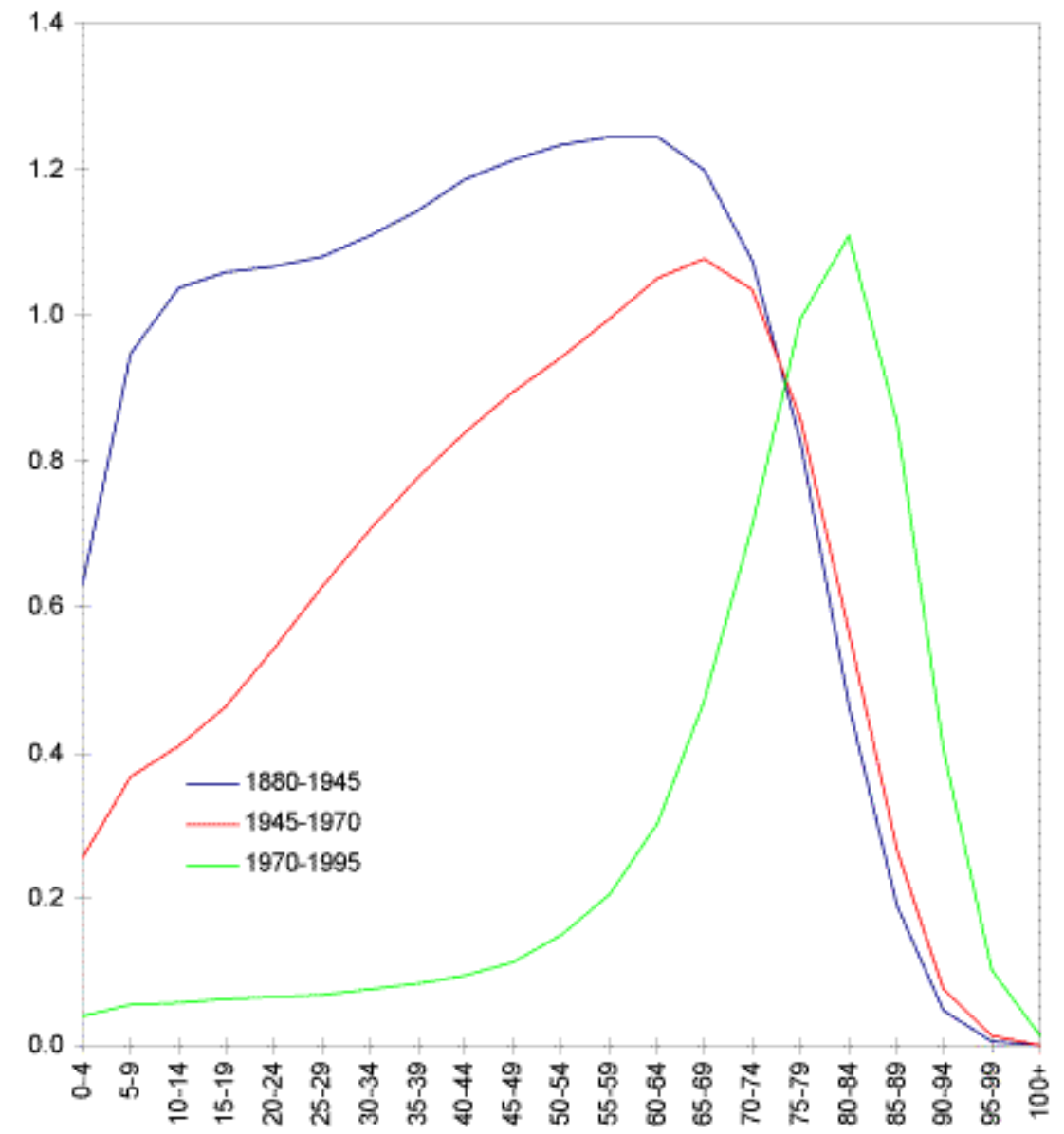


Figure 4. Years added to life by age and sex at different stages of transition.

Male

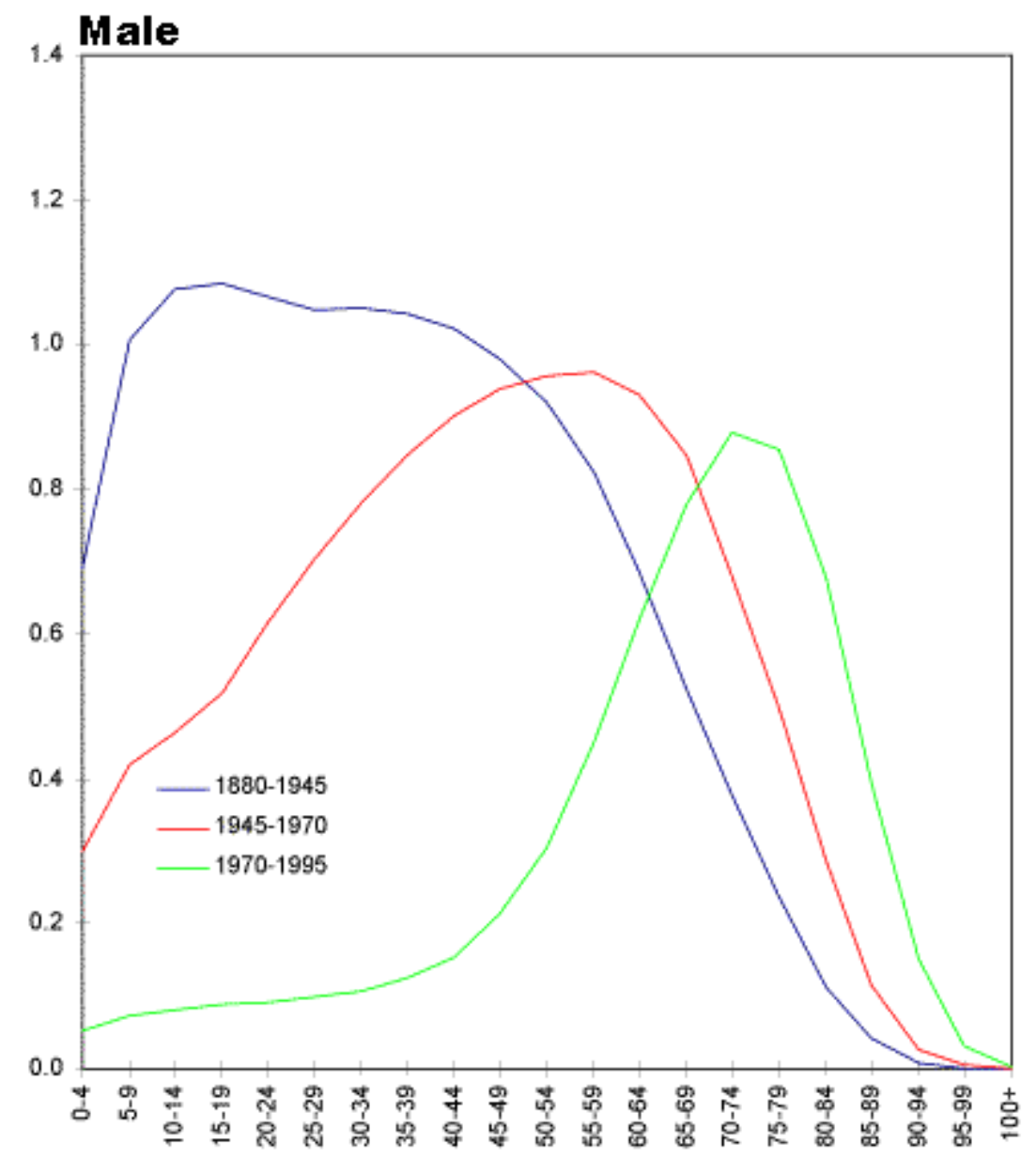

